\section{IMMANENCE AMID TRANSCENDENCE}

Humanity and Deity

By Wilbur Marshall Urban. Pp. 479. (London : George Allen and Unwin, Ltd., 1951.) 25s. net.

$\mathrm{T}$ is good that occasionally an author should offer 1 his book to the public with little regard to the usual formalities-the compelling reasons for writing it, the incapacity to do so, and the rest. This is fundamentally Prof. W. M. Urban's position; and the reason is that his book is almost a cri du cour, needing no apology and expecting no favours. True, we find his reluctance to set forth on his quest charmingly expressed, and the natural, but all too superficial, charge of escapism (from the turmoil of the Second World War) discounted well in advance. Yet, sooner or later, wisdom is justified of her children, and this complex contribution to con. temporary thought will assuredly find a permanent niche.

Readers who have not studied Prof. Urban's earlier volumes will find themselves at a disadvantage, because these pages show-it is their strength and their vulnerability combined-the characteristic urge to discover a common denominator between factors commonly, but not always correctly, assumed to be incommensurable. In this case the search is for a God who is immanent and yet transcendent. As everyone knows, there is one way, and only one, in which this is likely to be in the least successful, and that is by following the path of what is professionally known as traditional theism. Immanence left to run riot produces inevitably an irresponsible pantheism, whereas unrationed transcendentalism usually ends up in an orgy of deism, with all the attendant drawbacks inherent in the conception of the 'absenteelandlord' type of Creator. Well may we beware of the majestic but melancholic Kierkegaard, and his successors the Barthians of our own day, constructing a religion of paradox and crisis, which seems to fit all too easily into the world of our twentieth-century experience. Not without justification did Whitehead once remark that it was the medievalists who walked by reason and the moderns by faith. Most of this is implicit in what Prof. Urban has to tell us : he tends to be somewhat repetitious in places, and to make things more difficult than he need by the habit of introducing a subject with a protracted lemma (by no means unnecessary), but omitting to be clear at what point the prolegomenon ends and the proposition he wishes to establish begins. Unluckily, there are no summaries by means of which his arguments can be clinched.

Thus, in a review of reasonable length, one is obliged to pass over in silence much erudition displayed in the discussion of language, myth, symbolism, and the axiological development as it is enmeshed-perhaps even enshrined-in the writings of the scholastics, and of the present virile exponents of Thomism. An excellent point should be noted en route, namely, that the law of contradiction is only applicable in a plane of discourse which has previously been agreed. It is not 'transferable'. In symbols, we should be careful to write

$$
\{\sim[p \sim p]\} p \text { of } d \text { const. }
$$

rather than leaving it vague, as we are unconsciously prone to do. Much of the heat generated during the past century over the science versus religion conflict might have been largely avoided by this simple precaution. In our own day, 'what science really says', and, for that matter, 'what religion really says' are subjects only debatable with a similar restriction. In fact, Prof. Urban examines both their credentials, and sets them their bounds.

It seems likely that the main thesis-the degree of balance tolerable between immanence and transcendence-will be judged in the long run by the author's handling of the doctrine known as analogia entis, and by his treatment of Christian mysticism. Beside these two items, the remainder of the book is likely to be assessed as of secondary consequence, but in the nature of a treasure out of which a scribe can bring forth things new and old. Yet with the analogia entis we are confronted with perhaps the greatest attempt ever made by philosophical theologians to stabilize the relationship between deity and humanity; and stabilization there simply must be, if true knowledge is to abound. Two interpretations of the doctrine are possible, and common. One is that, starting from finite perfections, and following the path of empirical reasoning, the divine perfections are eventually attained. (This, by the way, is how the Thomistic principle is normally regarded.) Alternatively, it is necessary to postulate a special kind of intuition, by means of which our human attributes are modelled so as to become conformable to the Divine. An extension suggested by Prof. Urban does not appear to me to help matters a great deal, in view of the fact that a much more precise formulation-in English - is to be found in two books by E. L. Mascall (1943 and 1949) to which no reference whatever is made. This seems a curious omission, but the aims are broadly similar, namely, to assert that Deity has no need of creation, but that Creation has every need of Deity. Nobody has ever seriously suggested, in this context, that the Deus philosophorum is the same as the God of the Christian. The essence is that the former can never be inconsistent with the latter.

Towards the close, we are faced with the strain of mysticism running through all human consciousness, from which it is deduced that it forms at least an element in philosophy. Certainly we find the tendency in Plato and in Aristotle, and it can be traced in most of the Arabic thinkers before Averroës, particularly in Avicenna. If this had not been so, it would be difficult indeed to account for much we find in the outlook of St. Thomas Aquinas. Acceptance and transcendence - these have been the constant companions of the greatest mystics. Noteworthy, too, is how they have been held inviolate by two such diverse minds as those of Baron von Hügel and Earl Balfour; and during this very year are appearing the works of Edith Stein, who, starting as a pupil of Husserl, ended as a Carmelite, and sealed her conviction with the message of the Kreuzeswissenschaft. All this is easy to discount, but far harder to appraise in the light of modern thought. Prof. Urban does not see himself in the role of a crusader setting out to establish these experiences by formal argument: he appears to be thinking aloud, towards the evening of a long life, as if to beckon to others, skilled in epistemological symbolism, to share his strife and to enter into his calm. It is almost to exclaim, with the Queen of Sheba at the court of King Solomon, "And behold, the half was not told me".

F. I. G. RAwLINS 